\title{
Art and Religion in a Post-Secular, Multi-Religious Society
}

Nika Spalinger

This volume addresses the power of images, their potential to offend: the power that can make us think of images as acting subjects rather than as passive objects. My essay explores this power by analyzing and discussing how offense is at work in five examples of contemporary artworks concerning religion.

As a premise it should be mentioned that, before 9/II, religion was seldom taken as a theme in the European contemporary art world, ${ }^{\mathrm{I}}$ and then mostly from a distanced, critical, ironic, or cynical perspective. Artworks that embraced religious elements in a more positive manner were prone to be dismissed as unsuitable to be shown in contemporary art institutions, ${ }^{2}$ as if religion were something offensive to the art world. Maybe one of the reasons for this attitude was that the battle for freedom of expression in the (Western) arts in the wake of the Enlightenment, with its emancipation from the moral and institutional power of (Christian) religious institutions, does not yet lie very far behind us. Silvia Henke and I still felt repercussions of this attitude when we decided to conduct a research project on Art and Religion in 2008. ${ }^{3}$ Many colleagues seemed rather disconcerted by our choice of subject. However, the relative lack of interest in religion in contemporary art changed rapidly after $9 / \mathrm{I} ; ;^{4}$ and after the attack on the editors of the Charlie Hebdo magazine on January I4, 2015, religion has become an inevitable topic. Clearly, the contemporary cultural sector has arrived in the post-secular era. Despite its rather secular orientation, it has to acknowledge that in our increasingly multicultural society, culture can no longer be considered without taking religion into account. Not doing so would come at the cost of excluding cultural players from non-Western cultures, as well as those who have not ceased to be religious despite ongoing processes of »unchurching.« 
Focusing on five artworks in Switzerland - most of them placed in public spaces - that explicitly address religion as a theme, this essay explores the interplay of religion, the artworks themselves, the artists, the context, and the public media. I chose these artworks because of the different ways they provoke and offend. Placed in various types of public space and represented in different public media (e.g. TV, radio, newspapers, etc.), they reached a large and diverse audience.

The first two works focus on the minaret as a prime symbol of Islam ${ }^{6}$ (salat by Johannes Gees, various churches in Switzerland, 2007; and Minarett by Gianni Motti, Kunsthaus Langenthal 2008). The other three focus on Christian symbols (Ecce Homo by Marc Wallinger, Trafalgar Square, London 1999; Cross by Valentin Carron, Art Basel 2009; and Meeting by Barbara Mühlefluh, Reformierte Kirche Stäfa, 2009).

\section{Salat}

On July 10, 2007, to the great surprise of many pedestrians, the Muslim call to prayer resounded simultaneously from five important church towers in Switzerland: the Grossmünster in Zurich, the Münster in Bern, the St. Leonhardskirche in St. Gallen, the Wildkirchli in Appenzell, and the Kloster Einsiedeln.

The well-prepared guerrilla action salat, ${ }^{7}$ which used clandestinely placed, automated loudspeakers, was commissioned by the action-art platform agent provocateur (Fig. I). The action provoked many different reactions among the public, from amusement to outrage, as shown in one of the videos ${ }^{8}$ documenting the event. After a short time, the police removed the loudspeakers. However, 
for the media ${ }^{9}$ it was a welcome story that was intriguing and generated speculation about the initiators of the action: the Swiss installation and performance artist Johannes Gees. ${ }^{10}$ Against the background of the current international controversy about disturbances by church bells, which questions ideas of freedom of religion and the equality of different religions in a multi-religious society, the sound of the Muslim call to prayer from a Christian church created a great ambiguity: was it to be interpreted as a disrespectful attack on Christians' integrity or as a sign of solidarity of the Christian church with the Muslim community, contesting the ban on the construction ${ }^{\text {II }}$ of minarets in Switzerland? Or was it an attack on Christianity by Islamic jihadists? ${ }^{12}$

The ambiguity dissolved after twenty-four hours, as soon as Johannes Gees released following statement:

Ever since 9/II, I have been thoroughly annoyed by the abuse of religion as a battleground in international relations and national political conflicts. In 2007 , a group of nationalist politicians initiated a referendum to ban the construction of minarets in Switzerland (of which only three existed). One of the planned new minarets was supposed to be built in a small city called Langenthal. Its height was 5 meters 25 centimeters. I feel that spreading fear among people can only be understood as a lack of trust in the liberal values that matter to me. So I decided to make a statement against those who abuse religion to fight against some of the most important values of our society, such as generosity, tolerance and freedom of religion. Being an artist, I chose the classic artist's strategy: provocation. ${ }^{13}$ 

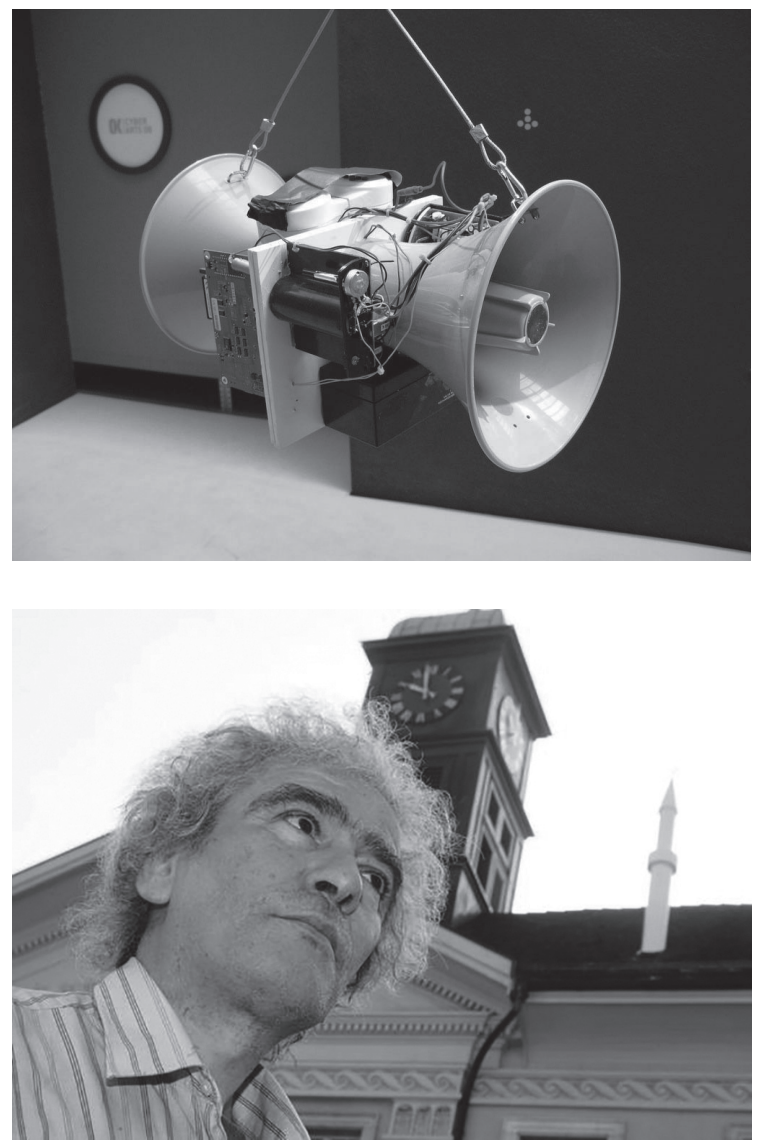

[FIG. 1]

Johannes Gees: salat, Bern,

Zurich, St. Gallen, 2007

[FIG. 2]

Gianni Motti: Minarett, Kunsthaus Langenthal, 2008

Later in 2008 , Gees was invited to present a new version of salat, which combined the muezzin prayer call with an Appenzeller Alpsegen (Appenzell alpine blessing) at various art venues. ${ }^{14}$ The juxtaposition of these two phonetically, amazingly similar religious songs raised questions such as: Why is one experi- 
enced as a provocation, while the other is classified as nostalgic, touristic, or nationalistic residue?

Because the first version of salat did not take place in an official institutional art framework, as was the case with the other versions, it evoked a conflict between two rights safeguarded by Swiss law: protection of the right of freedom of artistic expression ${ }^{15}$ and protection against attacks on the freedom of faith and the freedom of worship and cult and against racial discrimination (see the last part of this essay). As long as the action was not recognizable as an artwork - until the artist confirmed his authorship — it could be interpreted as an attack on the freedom of worship and cult. Had it been shown in the context of an art institution, the generally well-instructed public (culturally speaking) would have immediately interpreted the action as an artistic performance; in this case the provocative or offensive character would almost be something to be expected and hence not to be taken personally or too seriously.

\section{Minarett}

For Gianni Motti, ${ }^{16} \mathrm{a}$ Swiss artist of Italian origin who lives in Geneva, religion was a topic in several works. In 1989, for example, he simulated his own funeral procession amid a popular religious festival in Spain; in $201 \mathrm{I}$, he examined the Raelian sect in a video work (Fig. 2). ${ }^{17}$

Minarett was a small minaret tower $4.5 \mathrm{~m}$ high with a golden crescent moon on its top that the artist placed on the roof of the Kunsthaus Langenthal in Switzerland. It was part of the 2008 group exhibition entitled Average, ${ }^{18}$ which referred to 
the town's privileged role in market studies and voting forecasts based on its embodiment of the Swiss average for its structure and size. ${ }^{19}$

In this exhibition, Motti presented his Minarett as a response to the political debate concerning the planning application for a minaret submitted by the Langenthal Islamic Community in 2006. Supporters of right-wing politics reacted to this application with $8 \circ$ building objections, a demonstration, and a protest petition with more than $\mathrm{I}, \mathrm{\circ}$ o signatures from Langenthal residents.

According to the local newspaper Berner Zeitung, the artist aimed »to question the tolerance facing religious insignia of other faiths « and denied trying to provoke: »Artists have always used religious themes and symbols. ${ }^{20}$ He said that he had not expected any negative reception, since he had spoken with different people before installing his work and nobody had been against it. In fact, however, Motti's Minarett triggered numerous reactions in the media, ${ }^{21}$ where images of the artwork were shown prominently together with texts that made a direct link to the political discussion. The town mayor asked the curator of the exhibition to remove the artwork, arguing that he had not been correctly informed about the submission for the installation of the tower on the roof. Nevertheless, after public discussions on the freedom of art, the town council finally allowed Minarett to remain in place until the end of the exhibition.

In the following years, it took many discussions about the construction of the real minaret before the courts decided in 2012 that it could be built, as the planning application had been submitted before the adoption of the minaret ban in 2009. A reminder: the political controversy over the construction of new minarets had begun in Switzerland in 2007 . In 2009, against all expec- 
tations, the majority of the Swiss population voted in favor of the initiative to ban the construction of new minarets; since then, the ban has been anchored in the Swiss Federal Constitution. ${ }^{22}$

\section{Cross}

The Cross is an II-meter black wooden cross that Valentin Carron, represented by the Swiss Gallery Eva Presenhuber, placed in front of the main entrance to Art Basel, the international art fair, in 2009. The Swiss painter, sculptor, and installation artist lives in Canton Valais, a Catholic canton in the southwest of Switzerland. He represented Switzerland at the 2013 Venice Biennale, where he presented, among other objects, an 8o-meter, two-headed iron snake throughout the space, which was meant to welcome and guide visitors through the show. ${ }^{23}$ A series of flat-pressed brass instruments cast in bronze were reminiscent of a crushed brass band. The wall pieces named Windows were made of fiberglass and recalled stained glass windows of churches from the i950s. Carron's work is based on appropriation strategies related to Pop Art, as introduced by the artists Marcel Duchamp, Andy Warhol, and Elaine Sturtevant. In his work, he creates his own symbolic system, using images and forms from very different contexts: traditional and religious symbols, archeological artifacts, and sculptural works from art history and his own research in the field of sociology. At the same time, he plays with strong contrasts and ambiguity. 


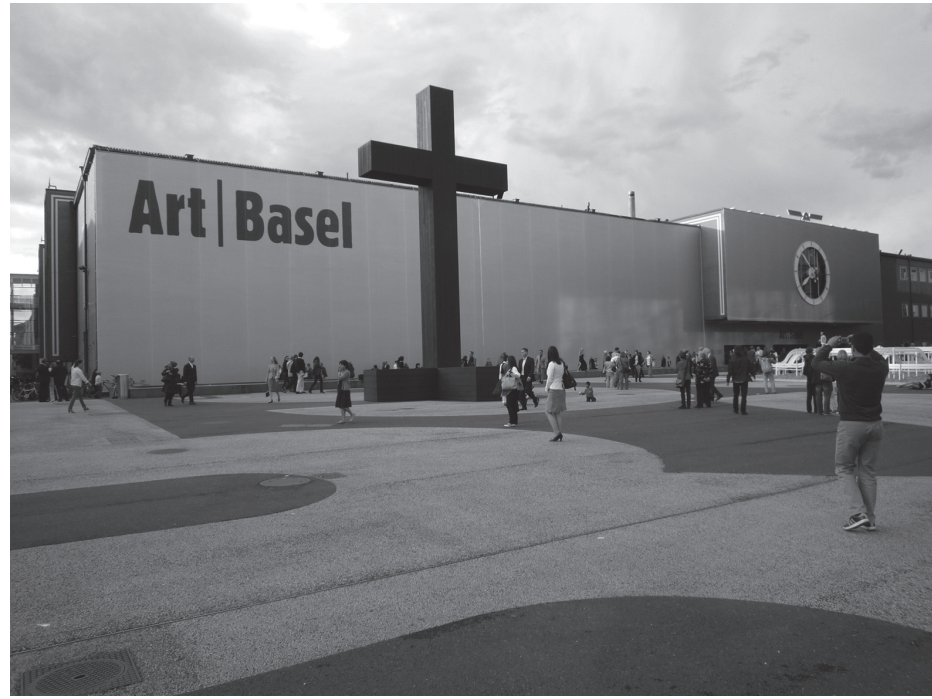

[FIG. 3]

Valentin Carron: Cross, Art Basel, 2009

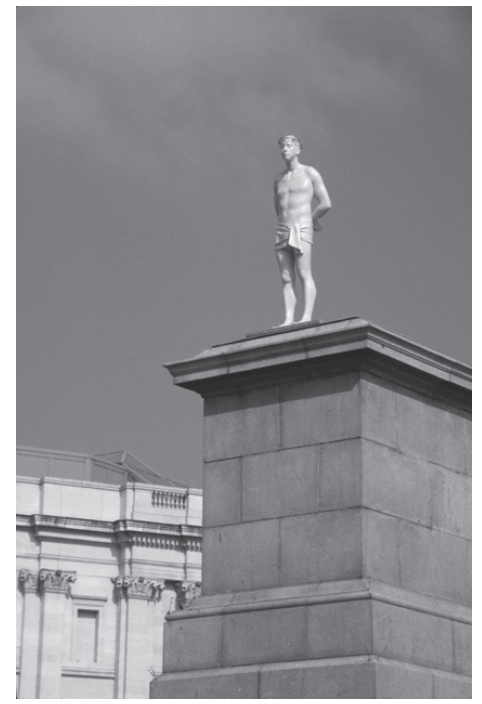

[FIG. 4]

Mark Wallinger: Ecce Homo, fourth plinth, Trafalgar Square, London, 1999

In his work Cross, the artist referred to the many roadside crosses in the Catholic Canton Valais, as well as to Minimalism (Fig. 3). The work could also be understood as an ironic reference to contemporary art as a new religion for the super-rich. In an interview with a Protestant online review, Thomas Jarek, ${ }^{24}$ an assistant at Carron's Gallery, said that the artist had produced a number of crosses that seemed to be made from a strong, hard material, but were in fact a very light polystyrene. The intention of the artist was thus to create a contrast to the weightiness of the Christian symbol. With the huge black wooden 
cross at Art Basel, the artist questioned the symbolic impact of the cross by showing it as a minimalist, geometric sculpture, reduced to pure geometric forms. Although Cross was covered by several important public media channels, ${ }^{25}$ the broadcast debates about it did not suggest that Cross was perceived as offensive. For some, it was not even clear whether it was a normal cross or an art work. The lack of provocation might be owed to the specific place and context of Art Basel, where it was immediately interpreted as an artwork. Most of the Swiss, like a large part of the international art world public, have a Christian background and a rather distanced relationship to religion in general, as a recent study shows. ${ }^{26}$ Notwithstanding the monstrous size of the cross, they were not likely to be offended by the work of an artist who shared a similar attitude.

In his insightful text on Valentin Carron, the art critic Jasper Adams quotes Eric Hobsbawm's famous The Invention of Tradition (1992), in which the latter suggests that if Europeans celebrate their important symbols and rituals with increasing vigor, this could be read as an indication of the impending loss of importance rather than as an expression of their unbroken belief in their cultural impact and continuity. I share Adams' view concerning the ambiguity of artist's position:

Is Carron a cynic? The question cannot be answered outright. His work blocks the possibility of catharsis at every turn, and radiates a contagious disenchantment. At the same time, there is a sense that the frustration he induces in his audience is not different to the frustration he experiences: a genuine exasperation at the emptiness at the heart of contemporary culture. ${ }^{27}$ 


\section{Ecce Homo}

For London's Millennium Festival in 1999, the well-known artist Marc Wallinger placed a life-sized marble statue of Jesus wearing a crown of barbed wire, his hands bound behind his back, on an otherwise empty plinth at Trafalgar Square (Fig. 4). Positioned at the edge of the massive plinth, the statue looked very small and vulnerable. With the title »Ecce Homo, « Wallinger quoted the words of Pontius Pilate at the crucifixion. The statue was quite popular with the public and was later shown at the 200 I Venice Biennale, where Wallinger represented Britain. In this artwork, Wallinger, who has produced several other artworks on religious topics, ${ }^{28}$ reflected on the role of religion at the Millennium celebration and said in an interview:

The Millennium dome was this big empty space without an idea of what it was celebrating. In a way, Christianity or Christ was the elephant in the room and no one was addressing this, and that is how I came up with the figure of Christ. ${ }^{29}$

This work did not use any obviously offensive image or strategy. Nevertheless, it seemed to have had a stronger critical impact than the other works described. Considering the large number of important publications mentioning the work to this day, I think this is due to its subtle demonstration of the shrinking of Christian belief in Western Christian society. ${ }^{\circ}$ 


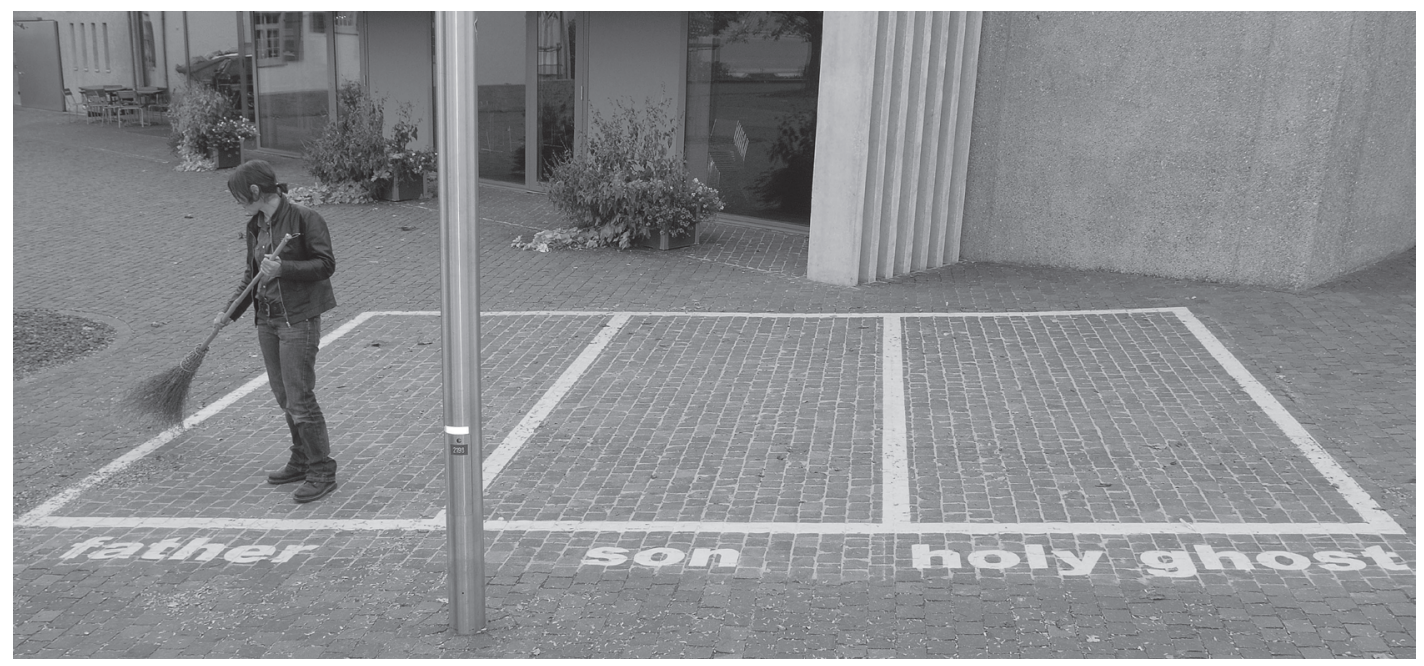

[FIG. 5]

Barbara Mühlefluh: Meeting, Kirche Stäfa, 2010

\section{Meeting}

The artwork Meeting by the Swiss artist Barbara Mühlefluh consists of three parking places reserved for Father, Son, and Holy Ghost. It was commissioned in 2009 by the Protestant Church of Stäfa ${ }^{31}$ near Zurich to link the church with public space (Fig. 5). The artist mixed banal, everyday signs with a highly complex religious construction. By creating a parking place reserved - in English words - for the Father, Son, and Holy Ghost, Meeting asks in a pragmatic and laconic way: What is the place of religion in our shared public urban life and how can we translate religious concepts into a multicultural society? 
At first, people were irritated by the artwork. It led to vibrant discussions in the church parish; $3^{32}$ while some questioned its artistic value, one person even thought it was blasphemous. The artist replied to this reproach, »I did not want to hurt the feelings of anyone, but to do something for God. The parking places are like a chapel, a place for God, who is everywhere. «33 Despite the strong criticisms, the artwork is still there.

\section{Conclusion}

Based on the examination of the five contemporary artworks, I conclude that their offensiveness is rooted in different interdependent factors and very complex interactions in a highly diverse society. A basic factor is that contemporary art in its multiple forms is not easy to recognize as art if not presented in its usual institutional context (e.g., museums, exhibitions, art galleries).

Another factor is the open and ambiguous character of certain forms of contemporary art. This type of work, defined by Umberto Eco as »open artwork, «34 allows the audience to participate in the process of the construction of the artwork and its multiplicity of possible meanings.

The open artwork assumes the task of giving us an image of discontinuity. It does not narrate it; it is it. It takes on a mediating role between the abstract categories of science and the living matter of our sensibility; it almost becomes a sort of transcendental scheme that allows us to comprehend new aspects of the world. 
Sharing this openness with religion, ${ }^{35}$ such artworks have the potential to be instrumentalized for very different purposes. The openness and ambiguity of artworks may offer new views, but may also be instrumentalized by different interests, just as aspects of religion may also be instrumentalized. By virtue of their openness and ambiguity, the presented artworks contain more or less subtle strategies of provocation, which emerge in the particular combinations of commonly known symbols and specific contexts: with the cross in front of the Kunst-Messe Basel, a German-language play on words (Messe = Catholic mass) evokes the idea of art as religion.

A third factor is the multiplicatory effect that stems from visual, oral, or written public media. Artworks unfold their offensive power only when they are reported in the context of a provocative public discourse, thereby making them accessible to a larger audience.

Another factor is the conflicts between the laws concerning the freedom of artistic expression, the freedom of expression and information, ${ }^{36}$ and the law concerning the protection against attacks on the freedom of faith and the freedom of worship and cult and against racial discrimination ${ }^{37}$ in Swiss society.

According to Jürgen Habermas, ${ }^{38}$ a key characteristic of these highly diverse societies in the post-secular era is that religious and secular values appear together in various forms, yielding conflicts as described above. This characteristic was not seriously taken into consideration in the art world before 9/II, when art mainly addressed a rather small, well-educated, mostly white, (male) Western public, and thus excluded a large part of the population. The growing importance of art mediation ${ }^{39}$ in the art world, which helps a larger audience 
to access contemporary art, as well as the enormous number of shows, conferences, books, and articles whose theme is religion in Switzerland and in Europe since 9/Ir testify to a changing attitude.

I conclude that interdisciplinary shared knowledge is essential to understand and deal with the complexity of inter- and transcultural religious relations in our societies - also in the art world - and I am positive that the growing number of inter- and transdisciplinary collaboration $s^{40}$ among artists, art institutions, and schools with players of different cultural and religious backgrounds promotes an informed, open, respectful, and self-critical discourse in our society on contemporary forms of (visual/artistic) representation and dialogue, a discourse that takes into consideration the given variety of religious and secular values and perspectives both in art institutions and in the public sphere. This discourse also inspires artists to continue creating interesting, criti$\mathrm{cal}$, and stimulating works that address a larger, multifaceted society, rather than merely a small, privileged part of it.

1 Cf. Alastair Sooke: Does modern art hate religion? For centuries, the church was a powerful force that shaped art - but this has changed, BBC Culture, Oct. 21, 2014 , http://www.bbc.com/culture/story/20140602-doesmodern-art-hate-religion (accessed on June 5, 2016).

2 One of the artists we interviewed in the context of the research project told us that his work had been rejected from a contemporary art space because it seemed religious - this was in the 1980 s.
3 The research project Holyspace, Holyways investigated in the relations between contemporary art and religion in the context of the public spheres. See Silvia Henke / Nika Spalinger/Isabel Zürcher (eds.): Kunst und Religion im Zeitalter des Postsäkularen. Ein kritischer Reader, Bielefeld, 20 I2.

4 In our investigation, we noted more than 40 exhibitions concerning religion $\&$ art in the period between 2000 and 2008 in important art venues such as ZKM Karls- 
ruhe (in 2002 , Iconoclash. Jenseits der Bilderkriege in Wissenschaft, Religion und Kunst, and in 2008 Medium Religion); Hygienemuseum Dresden (in 2004, Die Zehn Gebote); and Centre Pompidou Paris (in 2008 Traces du Sacré).

5 As we could see, for example, at the 2015 Venice Biennale, where the Swiss artist Christoph Büchel, who was hosted by the Icelandic Pavilion, presented as his artwork an empty Catholic church that had, on his initiative, been transformed into a mosque. Cf. (dpa) Biennale in Venedig. Polizei schliesst Kunstprojekt, in NZZ May 22, 2015 , http://www.nzz.ch/feuilleton/kunst_architektur/polizei-schliesst-umstrittenes-kunstprojekt-I.I8547754 (accessed on June 9, 2015).

6 Symbol = something $($ object, sign, image $)$ used to represent something else, usually something immaterial. In this case, the symbol for Islam.

7 The word salat, also spelled salah, Arabic șalāt, the daily ritual prayer enjoined upon all Muslims as one of the five Pillars of Islam (arkān al-Islām), http://www. britannica.com/EBchecked/topic/518979/salat, accessed June 9, 20I5; and cf. Prix Ars Electronica 2008: Hybrid Art: Honorary Mention, http://www.ok-centrum.at/?q=en/content/presse/7or (accessed on June 9, $2015)$. Cf. video from July II, 2007, https://www.youtube.com/ watch? $=\mathrm{VX}_{3} 8$ lecektM (accessed on March 25, 2015).

9 For example the culture channel of the Swiss TV SFI, cf. http: www.srf.ch/play/tv/kulturplatz/video/ muezzinruf-fuer-christen-satanische-verse-fuer-muslime-\% $2 \% 80 \% 94$-zuendstoff-im-dialog-der-religio (accessed on March, 2015)
${ }^{10}$ Cf. website Johannes Gees, www.johannesgees.com (accessed on March I8, 2015).

11 Some church congregations were against the ban; others opted for the ban. The posters for the plebiscite in 2009 show the ambiguity of Swiss society concerning freedom of religion. Cf. www.swissinfo.ch/ger/minarettverbot/590418 (accessed on June 3, 2016).

${ }^{12}$ Gees told me in 2015 that he had received a number of e-mails from members of the Islamic community who had seen his work on the Internet and congratulated him on his work in this sense.

${ }^{13}$ Cf. website Johannes Gees, www.johannesgees.com (accessed on March I8, 2015).

${ }^{14}$ E.g., in Linz at the Ars Electronica 2008, where Gees work received a Honorary Mention for Hybrid Art; in the exhibition Shifting Identities - Swiss Art Today at the Kunsthaus Zurich; as part of the exhibition Moral Imagi nations at the Art Museum Thurgau, a former hermitage.

${ }^{15}$ Cf. Swiss Constitution, http://www.gesetze.ch/sr/ 311.0/311.0_027.htm, and a text concerning salat on the website of the Kunstmuseum Thurgau, http://www. kunstmuseum.ch/xml_r/internet/de/application/di2/ fir3.cfm?action=werk. show\&id= $=$ II 6 (both accessed on June 9, 2015).

${ }^{16}$ Cf. Gianni Motti, http://de.wikipedia.org/wiki/ Gianni_Motti; Gianni Motti, Migros Museum Zürich, Frieze. Published on April 5, 2004 by Tirdad Zolghadr, http://www.frieze.com/issue/review/gianni_motti/, March 29, 20I5 (all accessed on June 9, 2015).

17 The Raelian sect is an UFO religion founded in 1974 by Claude Vorilho. Motti had been observing the Rae- 
liens with interest for several years, as described on the site of the Space Place, cf. http://www.orbit.zkm. de/?q=node/368 (accessed on June 9, 2015). See Carly Machado: Prophecy on stage: fame and celebrities in the context of the Raelian movement, in B. Meyer (ed.): Aesthetic Formations. Media, Religion and The Senses, New York 2009, pp. 207-224.

18

Average $=$ Durchschnitt. Cf. http://www. kunsthauslangenthal.ch/index.php/average.en.htm. (accessed on March 30, 2015).

${ }^{19}$ Kathrin Hofte-Fankhauser / Hans F. Wälty: Marktforschung, 3rd edition, Zurich 2011, p. 92.

${ }^{20}$ Cf. http://www.bernerzeitung.ch/region/emmental/ Provokativer-Durchschnitt/30668615/print.html (accessed on March 30, 2015).

${ }^{21}$ Cf. http://www.tagesanzeiger.ch/kultur/kunst/Allahu-akbar-MinarettKunst-erhitzt-die-Gemueter/story/12568996; http://www.srf.ch/play/tv/kulturplatz/ video/der-minarett-streit-in-langenthal-\% $\mathrm{C}_{2} \% 96$-derkuenstler-gianni-motti-nimmt-stellung?id=ec $8 f_{397}$ d84bb-44od-aefo-93bcebf 449 ba; https://www.woz.ch/I35C (all accessed on March 30, 2015).

${ }^{22}$ Cf. http://de.wikipedia.org/wiki/Schweizer_Minarettstreit (accessed on March 29, 2015).

${ }^{23}$ According to the artist in an interview given in the context of the Venice Biennale 20I3, cf. http://uk.phaidon.com/agenda/art/articles/2013/may/15/swiss-artistbrings-scooter-to-venice/ (accessed on May 30, 2015).

${ }^{24}$ Kirchenbote http://www.kirchenbote-online.ch/dedi/ projektor $/$ index $\cdot$ php? idcatside $=50 \&$ nid $=975 \&$ archiv $=I$ (accessed on June I2, 2014).
${ }^{25}$ Alain Bieber/Ute Thon/Heinrich Schmid: Bling Bling in Basel, in Art Magazin, Oct. 6, 2009 http://www.artmagazin.de/kunstmarkt/19273/art_basel_2009_kunstmesse (accessed on March 29, 2015).

${ }^{26}$ Cf. Jörg Stolz: Religions, the State and Society. National Research Programme NRP 58, Final report, http: www.nfp58.ch/e_projekte_formen.cfm (accessed on March 29, 2015).

${ }^{27}$ Cf. Adam Jasper, Valentin Carron: Alpine aesthetics and Modernism. Imitation and a boar's head, in Frieze, issue 107 (2007), p.136, http://davidkordanskygallery. com/artist/valentin-carron/\#press (accessed on March 29, 2015).

${ }^{28}$ Cf. Madleine Schuppli: Marc Wallinger und die Religion, in Madleine Schuppli (ed.): Marc Wallinger. Ecce Homo, Aargauer Kunsthaus Aarau, 2008, pp. 49-63.

${ }^{29}$ Fourth plinth: Marc Wallinger: Anthony Reynolds Gallery London 1999, http://www.recreativeuk.com/ resource/fourth-plinth-mark-wallinger (accessed on June 9, 2015).

${ }^{30}$ Cf. Michail Bulgakow: Pontius Pilatus, in Mark Wallinger. Ecce Homo, exhibition catalog Secession Wien, 2003 , pp. 5-6; Charlotte Higgins: Bear man walks away with Turner Prize, in The Guardian, December 3 , 2007, Pp. I0-12.

${ }^{31}$ Cf. Irene Müller: Gott und die Welt. Zu Barbara Mühlefluhs Projekt Meeting, in: Henke / Spalinger / Zürcher (eds.): Kunst und Religion im Zeitalter des Postsäkularen (see note 3), pp. 83-90.

${ }^{32}$ Heinz Wilhelm: Parkplätze, in reformiert. stäfa, II/ 2009, http://www.kirchestaefa.ch/parkplaetze (ac- 
cessed on June 9, 20I5); Markus Kumpert: Der liebe Herrgott hat seinen eigenen Parkplatz, in Tages-Anzeiger, September I8, 2009, http://www.tagesanzeiger. ch/schweiz/gemeinde/Der-liebe-Herrgott-hat-seinen-eigenen-Parkplatz/story/20I25307 (accessed on June $29,2015)$.

33 Quotation from Daniela Schwegler: Drei Parkplätze sind für Gott reserviert, in reformiert. Kirchenbote Kanton Zürich, Nr. II, 29. October 2010, p. 2, www. reformiert.info/sites/default/files/pdf/e.../091030_REFORMZH.pdf (accessed on June 29, 2015), trans. by Nika Spalinger.

${ }^{34}$ Umberto Eco: The Open Work, trans. from Italian by Anna Concoghni, Cambridge/ Mass. 1989, p. 90.

${ }^{35}$ Here I refer to an open and a mbiguous character of religion, as described from a functional perspective following Clifford Geertz. Many aspects of religion are ambivalent; they can have positive or negative effects. Religion can, for example, give believers an orientation, but at the same time, it can lead them into isolation and dependency. The interpretation of religious writings and rules is also very open; they can be interpreted in many different ways. Willi Bühler/Benno Bühlmann/Andreas Kessler (eds.): Sachbuch Religion, Lucerne 2009, pp. 20-22.

${ }^{36}$ Cf. Federal Constitution of the Swiss Confederation https://www.admin.ch/opc/en/classified-compilation/19995395/index.html (accessed on June I, 2016). »Art. I6 Freedom of expression and of information:

I Freedom of expression and of information is guaranteed.

2 Every person has the right freely to form, express, and impart their opinions.

3 Every person has the right freely to receive informa- tion, to gather it from generally accessible sources, and to disseminate it. Art. 2r Freedom of artistic expression: Freedom of artistic expression is guaranteed.«

${ }^{37}$ Cf. Swiss Criminal Code (Book Two, Title Twelve Felonies and Misdemeanors against Public Order, on https://www.admin.ch/opc/en/classified-compilatio n/19370083/201501010000/311.0.pdf (accessed on June I, 2016). "Art. 26r Attack on the freedom of faith and the freedom to worship: Any person who publicly and maliciously insults or mocks the religious convictions of others, and in particularly their belief in God, or maliciously desecrates objects of religious veneration, any person who maliciously prevents, disrupts, or pub licly mocks an act of worship, the conduct of which is guaranteed by the Constitution, or any person who maliciously desecrates a place or object that is intended for a religious ceremony or an act of worship, the conduct of which is guaranteed by the Constitution is liable to a monetary penalty not exceeding I 80 daily penalty units.

Art. 26I-2I8 Racial discrimination: Any person who publicly incites hatred or discrimination against a person or a group of persons on the grounds of their race, ethnic origin, or religion, any person who publicly disseminates ideologies that have as their object the systematic denigration or defamation of the members of a race, ethnic group, or religion, any person who with the same objective organizes, encourages, or participates in propaganda campaigns, any person who publicly denigrates or discriminates against another or a group of persons on the grounds of their race, ethnic origin, or religion in a manner that violates human dignity, whetherverbally, in writing, or pictorially, by using gestures, through acts of aggression, or by other means, or any person who on any of these grounds denies, trivializes, or seeks justification for genocide or other crimes against humanity, any person who refuses to provide a 
service to another on the grounds of that person's race, ethnic origin, or religion when that service is intended to be provided to the general public is liable to a custodial sentence not exceeding three years or to a monetary penalty.«

${ }^{38}$ Cf. Jürgen Habermas: Glauben und Wissen. Rede zum Friedenspreis des Deutschen Buchhandels, Frankfurt on the Main 200I, p. I2ff.

39 "Art Mediation is an established term in Germanspeaking countries: ") Mediation < is in fact an ancient form of conflict resolution, which consists of the mediator positioning his or herself between two parties without taking sides, or passing judgment on either of them. An art-mediator thus facilitates dialogue and the exchange of knowledge by stimulating opinions through what the viewer sees and the associations they make with the work directly in front of them. "Cf. http://mio. manifesta.org/en/education/art-mediation/ (accessed on June 8,2016 ).

${ }^{40}$ See, for example, the interdisciplinary project "Global Prayers - Redemption and Liberation in the City«, an academic and artistic research project that aimed to investigate the renaissance of religion in the world's metropolises, is an interesting example, cf. http:// globalprayers.info/research/ (accessed on June I, 2016). 